Income Tax

Colonial Appointment-Remittances

"C. C."' is employed in West Africa, and usually visits the United Kingdom, where he maintains a home, every twelve months. He pays British income tax on that portion of his earnings which he sends or brings to this country. He will not, however, be in the United Kingdom between March 25th, 1930, and April 25th, 1931. Will he be liable to income tax here in respect of the financial year ending April 5th, 1931?

** No. During a year in which " C. C." does not return to the United Kingdom his wife is liable to taxation as a feme-sole, but only in respect of remittances made to her out of " property" ; remittances made out of the husband's earnings do not fall within that category, and in such circumstances are not liable to British income tax.

\section{Replacement of Car}

"C. H. C." bought a car in 1920 for $£ 550$, and in January, 1931, sold it for $£ 20$, and bought a new car for $£ 23710$ s. Depreciation has not been claimed for income tax purposes. The car is used only partly for professional visits, and only one-half of the running cost has been debited to professional earnings. What can he claim?

** He can claim as a professional expense a reasonable proportion (apparently one-half) of the out-of-pocket cost of replacement-that is, one-half of $£ 21710 \mathrm{~s} .=£ 10815 \mathrm{~s}$. That amount will have to be regarded as expended in January, 1931 ; consequently, if he makes his statement of accounts out to December 31st the deduction will affect his profits for the year 1931 and his income tax liability for the year 1932-33, but if his annual accounts are made out to, say, March 31st, then it will operate to reduce his liability for 1931-32.

\section{First Year of Partnership}

C. D." became a partner in a firm as from April 1st, 1930 ; prior to that date he had been acting as a locumtenent. How should his liability for $1930-31$ be calculated?

** He will be liable to account for tax on his share (less his personal allowances, etc.) of the firm's gross assessment for 1930-31, and that assessment will presumably be calculated in the usual way on the amount of the profits earned in 1929-30 by the then existing firm. His liability to assessment as a locumtenent does not extend to periods subsequent to April 1st, 1930.

\section{LETTERS, NOTES, ETC.}

\section{Mammary Abscess}

"Suburban G.P." writes: Within the past few weeks I have had three cases of mammary abscess occurring in primiparae three to five weeks after confinement. All the patients had been confined at a maternity home under excellent conditions, and were discharged after a normal fourteen days' puerperium. Breast abscess results in a good deal of distress, physical and domestic, while the life of the young infant can be seriously jeopardized; it may be a question of months before the mother completely recovers. In searching for a possible causation I feel strongly that the application of hardening agents-for example, spirit-to the nipple ante-natally may constitute a weak link in the chain of ante-natal " do's " and " don'ts." Curiously enough, the left breast was involved in each case. I do not offer any explanation, but I should be glad to know the opinions of some of yeur more experienced readers.

\section{Graves's Disease: Intercurrent Pyrexia}

Dr. J. G. Bennetr (Hyde, Cheshire) writes: Of late we have had quite a number of demonstrations illustrating the effect of one disease upon another, often with a markedly beneficial result. Of such a type is the benign alteration which ensues when suitable cases of general paralysis of the insane are inoculated with the virus of malaria. I have a case which illustrates a similar phenomenon, but here the primary disease is exophthalmic goitre. The patient is a cotton cloth tester, and he is a typical sufferer from moderate Graves's disease, having all the cardinal signs of the complaint, including a constantly rapid pulse, usually 110 to 120 per minute. There is also extrasystole. As a rule he can do his work well, and for his age (62) he does not suffer great handicap. Whenever he gets an influenzal cold, with its subsequent deflorescent perspiration, the latter heralds a wonderful slowing and regularity of his pulse. For weeks after such an attack his heart beats regularly and slowly, he feels in splendid condition, and can work much better and with less fatigue than before the attack. This beneficial result has occurred on four or five occasions since I first treated him ten years ago, and the connexion between the two diseases is, to my mind, undoubted. Whether the antibodies brought into being by his influenza have neutralized toxin due to the exophthalmic goitre, or whether the influenza has reduced secretion at its source in the thyroid gland, I do not know, nor can I say whether treatment on these lines in every case of Graves's disease would be a specific, but the phenomenon appears to me to be well worth further investigation in the laboratory.

\section{A Twin Monster}

LR. M. Y. Lum (Kuala Lumpur) reports the birth, on September 19th, 1930, in the Chinese Maternity Hospital, Kuali Lumpur, of a double monster. The jirst head delivered was followed by the corresponding arms. Then the breech had to be extracted manually. The breech of the second child was delivered next. followed by the head. Dr. Lum adds: There was only one placenta, and one cord, which was attached to the lower surface of the band connecting the twins; the connecting band measured 10 inches in circumference. The twins were healthy, and weighed : $\mathbf{8} \frac{1}{2} \mathrm{lb}$. together. There was a distinct systolic murmur in the smaller child. Both children had to be fed independently. The parents, poor vegetable gardenfirs, sold the twins to a friend, who put them up for exhibition on the tenti

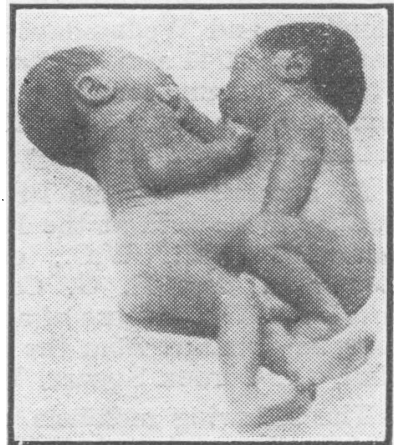
day. In consequence, appa-

rently, of continuous exposure and bad artificial feeding, the twins contracted diarrhoea and fever on the eighteenth day, and died on the tiventy-first day after birth. The smaller one died first, followed three hours later by the larger one. At the post-mortem examination all the organs were found separate, with the exception of the livers, which were so closely joined together that there was only a faint line of demarcation. There were two gall-bladders. The foramen ovale was patent in the smaller child. The photograph reproduced was taken on the fourth day after birth; the smaller child is on the right.

\section{Pronunciation of Laboratory}

"M.A., M.B." writes: The B.B.C. has adopted the very ugly pronunciation of laboratory thus, labōratory. All the eminent scientists at the studio talks have adhered to the old form laborătơry, including Lord Moynihan and Sir William Bragg. It would be ugly were we to say elabōrate, and equally ugly is the pronunciation of rätions as rations, as the B.B.C. studio has pronounced it.

\section{Treatment of Addison's Disease}

Several cases of Addison's disease have been treated in this country with extract of suprarenal cortex prepared according to the process of Swingle and Pfiffner (Science, March 21st, 1930). Messrs. Allen and Hanburys inform us that they have a limited supply of this extract, particulars of which can be given on application.

\section{Corrigendum}

The Librarian of the Liverpool Medical Institution writes: The paper read at this institution entitled "Cardiac output and oxygen utilization in heart disease" was the joint work of Drs. I. Harris and I. J. Lipkin. Owing to an oversight Dr. Lipkin's name was omitted in the account of the meeting sent for publication and appearing in the British Medical Journal of February 28th.

\section{Vacancies}

Notifications of offices vacant in universities, medical colleges, and of vacant resident and other appointments at hospitals, will be found at pages $50,51,52,53,54,55$, 58 and 59 of our advertisement columns, and advertise ments as to partnerships, assistantships, and locumtenencies at pages 56 and 57

A short summary of vacant posts notified in the advertisement columns appears in the Supplement at page 83 . 